\title{
THE CONCEPTUAL BASES OF MULTINATIONAL AND GLOBAL COMPETITIVENESS ENVIRONMENT AND STRATEGIC ALLIANCES
}

\author{
Yusupov Asomiddin Soatovich, \\ PhD in Economics, Doctoral student (DSc) \\ Tashkent State University of Economics
}

\section{DOI: https://doi.org/10.31435/rsglobal_ws/31052019/6519}

\section{ARTICLE INFO}

Received: 11 March 2019

Accepted: 09 May 2019

Published: 31 May 2019

\section{KEYWORDS}

transnational corporations and international companies, multinational enterprise, strategic alliance, international business, international movement of capital, goods and services, special enclaves, multinational and global competition.

\begin{abstract}
Under the conditions of integration of national markets global competition environment is created in international markets. As a result of this competitors compete based on price and related conditions of competition. In the context of global competition the competitiveness of rival companies is proportional to its global competitive advantage. In the context of global competition, the competitiveness of rival companies is proportional to its global competitive advantage. In a multinational competition, companies are struggling for leadership in the national market and in a global competition, they fight for leadership in the world. In a certain network at the same time, one can observe both global and interstate multinational competition. This paper evaluates the increasingly important role and the interdependencies between multinational and global competition, technological innovations and the theory of international production.
\end{abstract}

Citation: Yusupov Asomiddin Soatovich. (2019) The Conceptual Bases of Multinational and Global Competitiveness Environment and Strategic Alliances. World Science. 5(45), Vol.3. doi: $10.31435 /$ rsglobal_ws/31052019/6519

Copyright: (C) 2019 Yusupov Asomiddin Soatovich. This is an open-access article distributed under the terms of the Creative Commons Attribution License (CC BY). The use, distribution or reproduction in other forums is permitted, provided the original author(s) or licensor are credited and that the original publication in this journal is cited, in accordance with accepted academic practice. No use, distribution or reproduction is permitted which does not comply with these terms.

Introduction. The relevance of the topic: The role fostering "Competitiveness" is a major issue in a recent strengthening of globalization ${ }^{1}$. In fact, the increased politicization of international business represents one of the most significant changes in business government relations over the last two decades ${ }^{2}$. The analysis is guided by the underlying theme of applying heuristically the economic theory.

This paper explores the increasingly important role of international business and the extent to which technological competitiveness depends upon the strategies of multinational companies (MNCs). This preliminary analysis is guided by the underlying theme of applying the economic theory to international production and technological innovation. The world's leading multinational enterprises routinely face barriers to entry to established international marketing networks, as evidenced by the emergence of multinational enterprises in Japan and Korea ${ }^{3}$. As a result, the list of the world's largest enterprises has changed only marginally in recent years. We make a discussion of international competitiveness and the role of international markets in fostering or hindering the pace of innovation.

\footnotetext{
${ }^{1}$ Paul Krugman. Competitiveness: A Dangerous Obsession., Foreign Affairs March/April 1994. //https://www.foreignaffairs.com/

2 T. L. Brewer, 'An issue-area approach to the analysis of MNE-government relations', Journal of International Business Studies, 23(2) (1992) 295-309.

${ }^{3}$ Bernard Michael Gilroy. International Competitiveness, Multinational Enterprise Technology Clubs and the Government Interface. //Trade, Growth, and Economic Policy in Open Economies Essays in Honour of HansJürgen Vosgerau. Springer Pages 13-30.
} 
On the basis of economic theory, we try to reflect international production and technology raises as the important issue of global decision making and finally, give some preliminary conclusions.

The concept of worldwide free trade competitive advantage is one of the oldest and most commonly acknowledged economic theorems: Haberler (1990), Baldwin (1992) and Broll (1993). Nevertheless, attempts to create equal conditions for the game through international competition may well serve as a possible substitute for trade policy (Vosgerau (1993). In practice, the real winners may continue to maintain or create new barriers to the movements of goods, people, capital, and technology (Behrman and Grosse (1990)). Consequently, protectionism adversely reigns.

In fact, the increased politicization of business represents one of the most significant changes in international business. Due to the high degree of mobility of international production, strong impacts upon relative competitive positions of nations are being perceived as a concern of competitiveness.

Since the mid-1970s, there has been a rapid acceleration of two mutually reinforcing trends the convergence in technical capabilities of industrialized nations and the global integration of formerly discrete national technical enterprises (Gugler and Dunning (1992)). No nation wishes to lose the global technology race ${ }^{1}$.

According to current research on the determinants of international competitiveness (for example, Porter (1990), Enderwick and Barber (1992, p. 269), the concept of "competitiveness" is very elusive.

Analysis and results: It is known that, in the presence of unrelated national markets, it is usually dictated by multinational or interstate competitiveness. At the same time, competition in the national market does not depend on another, in terms of coverage is of intergovernmental importance. For example, competition in the banking sector in France, Brazil, and Japan are different. That is, the reputation of a bank in a country, customer base, and competitive advantage does not affect the successful functioning of the financial sector in another country.

In sectors where exist multinational or intergovernmental competitions, since the company's strategy and competitiveness are limited to the territory of each country, its scope does not affect the territory of other countries.

As a result of interdependence and integration of national markets, it is observed the emergence of "international markets". In such circumstances, the competitors in different countries compete with each other. And in the end result, the global competitive environment is emerging in which the price and conditions of competition will be closely intertwined.

In a globally competitive environment, the company's overall competitiveness becomes apparent in its complex operations taking place around the world. So the market power of a global competitor is proportional to the number of its competitive advantages in different countries. In a multinational competition, companies compete for leadership in the national market, and in the global competition fight for leadership in the world.

As a rule, global competitiveness exists in the markets of automobiles, televisions, car tires, telecommunications, equipment, copiers, watches and commercial aircraft.

In a particular industry, one can also observe global and multinational competition simultaneously. For example, if multinational competition for cheap and average prices is observed in the hotel business and in business class and upper class is observed the environment of global competition.

Therefore, companies such as Nikki, Marriott, Sheraton and the Hilton, do having their own system of hotels in many international centers, continue to provide competitiveness worldwide by occupying rooms, maintaining a high standard of service.

There is also global competition in the engine lubrication network, in that Exxon, British Petroleum, Shell and other companies compete globally. As is known, and competitiveness of the national economy depends on the competitiveness of existing microcomponents, that is, enterprises, organizations and companies, and their effectiveness. Today, companies operating in international markets are based on six strategic approaches (Figure 1).

\footnotetext{
${ }^{1}$ Bernard Michael Gilroy. International Competitiveness, Multinational Enterprise Technology Clubs and the Government Interface. //Trade, Growth, and Economic Policy in Open Economies Essays in Honour of HansJürgen Vosgerau. Springer Pages 13-30.
} 


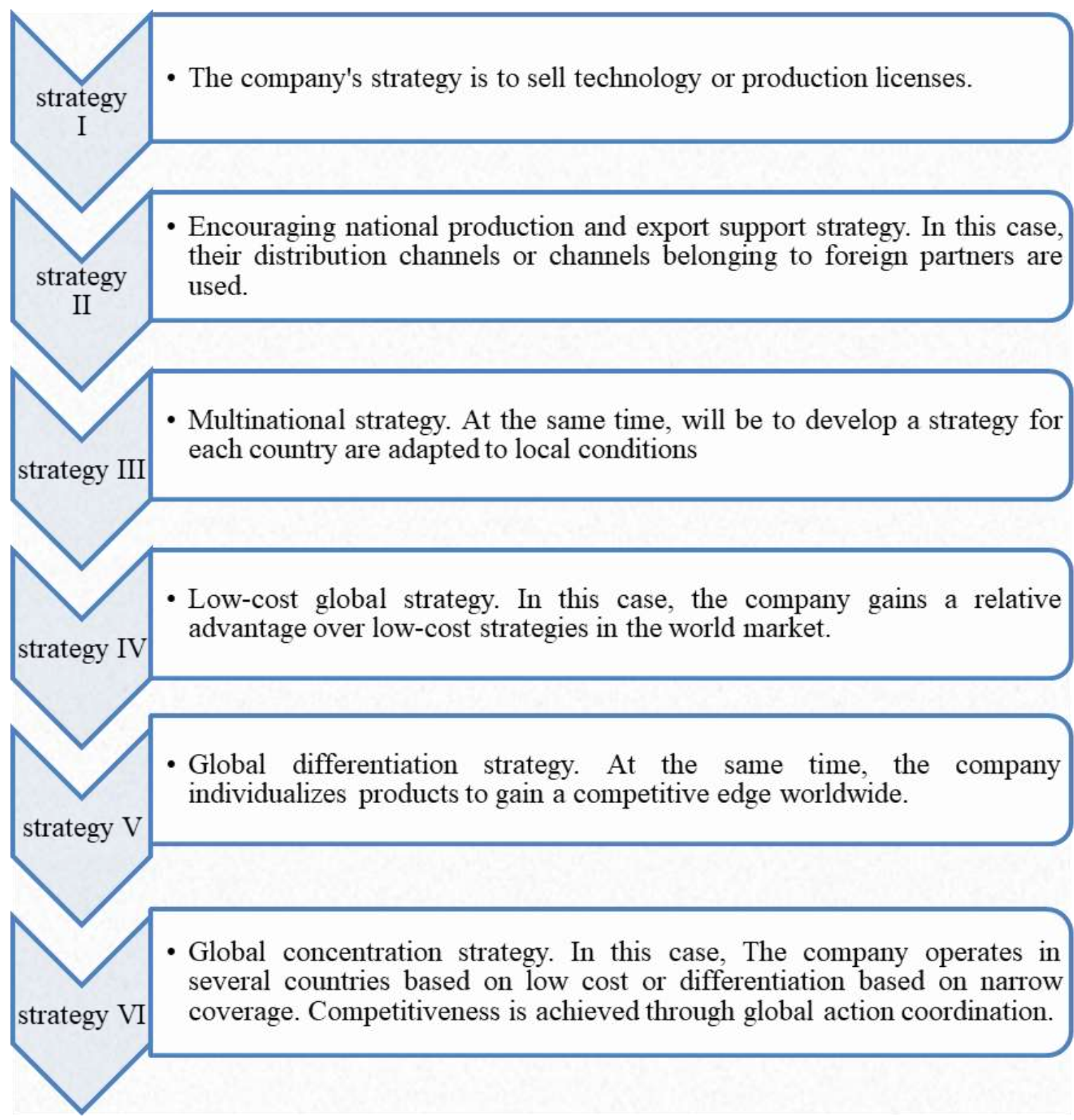

Fig. 1. Strategic international standards

Source: Designed by the author on the basis of logical analysis.

In addition, currently operating in international markets and ensuring competitiveness many companies actively support the "Stable Protection Strategy" (Figure 2).

The main purpose of this strategy - focused on making it difficult for competitors to enter the market, and the current competitive position, maintaining a competitive advantage by the company.

The advantage of a robust security strategy is that when growth opportunities are limited and even if the expansion of the market share does not increase profits its use gives a good result.

Comparing multinational and global strategies is complex, however, the use of export strategies for local enterprises to enter international markets is an important strategic task. This strategy actively used in Chinese, Korean, Japanese, and Western companies.

\section{A natural question arises: Should they follow multinational or global strategies?}

Multinational strategy arises due to significant differences in cultural, economic and political spheres in different countries. If the differences between national markets are significant, creating multinational strategies becomes even more complex. 


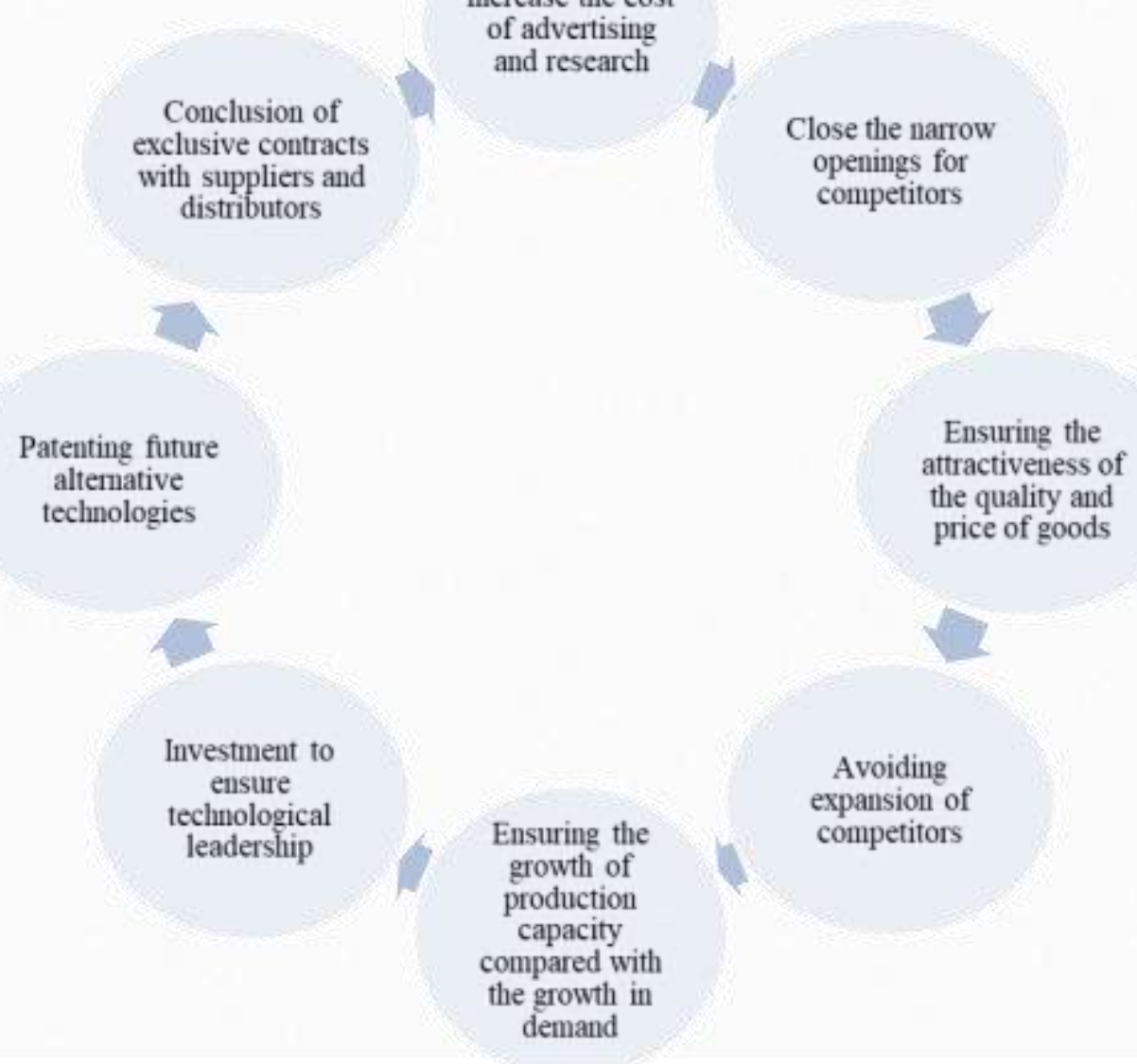

Fig. 2. "Stable Protection Strategy"

Source: Designed by the author on the basis of logical analysis.

The multinational strategy is compatible with existing multinational corporations, and the global strategy is consistent with global competitiveness.

The strong side of a multinational strategy is to choose a strategy that is fully consistent with a particular country.

But the multinational strategy also has its drawbacks: country;

- company strategy does not require serious strategy coordination outside the intended

- does not set the main goal of achieving competitive advantage.

Since a global strategy requires the same approach in all countries, due to low cost or differentiated strategy provides a competitive advantage over local companies.

In all countries where the company operates, if it applies the same strategy, the global strategy gives a good result.

Table 1. Differentiated aspects of multinational and global strategies

\begin{tabular}{|c|c|l|}
\hline $\begin{array}{c}\text { Types of } \\
\text { strategies }\end{array}$ & \multicolumn{1}{|c|}{ Multinational strategy } & \multicolumn{1}{c|}{ Global strategy } \\
\hline 1 & \multicolumn{1}{|c|}{2} & \multicolumn{1}{c|}{3} \\
\hline Strategic area & $\begin{array}{l}\text { Selected destination countries and } \\
\text { shopping areas. }\end{array}$ & $\begin{array}{l}\text { Countries are critical to the commodity } \\
\text { market, for example, North America, the } \\
\text { EU and the countries of the Pacific } \\
\text { (Australia, Japan, South Korea, and } \\
\text { South-East Asia). }\end{array}$ \\
\hline
\end{tabular}


Continuation of table 1

\begin{tabular}{|c|l|l|}
\hline 1 & \multicolumn{1}{|c|}{2} & \multicolumn{1}{|c|}{3} \\
\hline Business strategy & $\begin{array}{l}\text { A strategy that complies with the } \\
\text { conditions of each country. Interstate } \\
\text { strategy coordination is rarely used or } \\
\text { not used. }\end{array}$ & $\begin{array}{l}\text { The basic strategy is the same for all } \\
\text { countries. The strategy will be changed } \\
\text { when a condition is required or when } \\
\text { moving from country to country. }\end{array}$ \\
\hline $\begin{array}{c}\text { Commodity } \\
\text { strategy }\end{array}$ & Adaptation to local needs. & $\begin{array}{l}\text { Usually standardized products are sold } \\
\text { worldwide. }\end{array}$ \\
\hline $\begin{array}{c}\text { Production } \\
\text { strategy }\end{array}$ & Business is spreading in many countries. & $\begin{array}{l}\text { Enterprises are placed on the basis of } \\
\text { obtaining maximum competitiveness (In } \\
\text { low-cost countries, it is close to } \\
\text { mainstream markets and occupies large } \\
\text { areas or in order to use the magnitude of } \\
\text { the scale effect, the capacity of several } \\
\text { large enterprises is used). }\end{array}$ \\
\hline $\begin{array}{c}\text { Sources of raw } \\
\text { materials and } \\
\text { components }\end{array}$ & $\begin{array}{l}\text { A supplier who is located at the location } \\
\text { of the enterprise is preferred. (local } \\
\text { businesses meet domestic demand, } \\
\text { country of origin may require the use of } \\
\text { local raw materials). }\end{array}$ & $\begin{array}{l}\text { Work with attractive suppliers around } \\
\text { the world. }\end{array}$ \\
\hline $\begin{array}{c}\text { Marketing and } \\
\text { distribution }\end{array}$ & $\begin{array}{l}\text { Enterprises adapt to the culture and } \\
\text { experience of their country of residence. }\end{array}$ & $\begin{array}{l}\text { The focus is on coordinating the global } \\
\text { strategy, adaptation to the location of the } \\
\text { enterprise is not required. }\end{array}$ \\
\hline $\begin{array}{c}\text { Organization of } \\
\text { the company }\end{array}$ & $\begin{array}{l}\text { Leadership is organized in every } \\
\text { country, each branch operates } \\
\text { independently according to the } \\
\text { conditions. }\end{array}$ & $\begin{array}{l}\text { All major strategic decisions are strictly } \\
\text { governed by global headquarters. The } \\
\text { global organizational structure works to } \\
\text { adapt activities around the world. }\end{array}$ \\
\hline
\end{tabular}

Source: 1. Портер Майкл. Конкурентная стратегия: Методика анализа отраслей и конкурентов / Майкл Портер; Пер. С англ. - 3-е изд. - М.: Альпина Бизнес Букс, 2007. - 453 с.; 2. Калюжнова Н.Я. Конкурентоспособность регионов в условиях глобализации. М.: ТЕИС, 2003. - 526 с.

The global strategy has a higher status than the national market strategy. The company, using a global strategy, achieves high efficiency, establishing modern production and expand its market share by reducing costs. This could trigger strategic attacks against local companies in critical markets, promoting their brand wins the kindness of consumers.

Despite the state protectionist policy in the long term (10-20 years), global companies are able to cover potential markets. In this situation, domestic companies offer their governments to actively use trade barriers such as tariffs, import quotas, anti-dumping measures.

And to protect against attacks from companies seeking global advantage domestic companies must have multinational strategies and become a competitor.

The vulnerability of multinational companies lies in the fact that in spite of they tend to defend themselves to some extent from global companies in critical markets, are still weaker in competitiveness. And global competitors have a large market share and large modern enterprises.

Strategic alliances. Competitors in international markets differ not only in modern strategies but also for long-term goals. By these criteria can be divided into four categories of companies:

1. A global company seeking superiority or leadership. According to the strategic intentions of the company, such firms use one of the forms of global strategy.

2. A superior company defending in its domestic market. He can sell part of his products (up to $20 \%$ ) abroad.

3. The company, tending to diversify its sales in the global market. What is the reaction of a country that adopts its main strategic direction? Such companies use a multinational strategy and obtain most of the profits from foreign affiliates.

4. Purely national companies are not inclined to strengthen their positions in foreign markets.

Companies planning to export products plan to sell their products abroad through companies in low-income countries. Usually US, Japan and EU companies are trying to unite in strategic alliances. 
Strategic alliances - This is a joint partnership between companies aimed at strengthening their position in global competition with the independence of companies. To do this, they seek to use some competitive advantages (Figure 3 ).

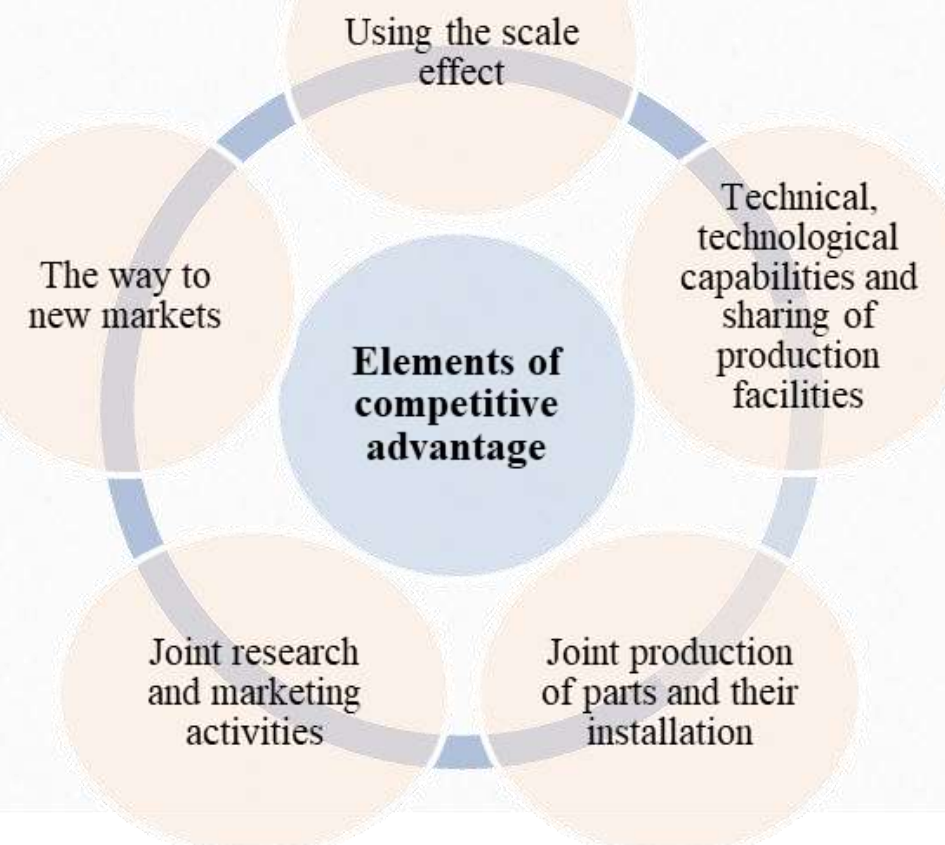

Fig. 3. The main elements of the dominance of strategic alliances' competition Source: Designed by the author on the bases of logistic analysis.

In this way, the alliance members evolve together. Every company in the Alliance has its own goals and motives. Such a situation creates some risks associated with their activities. For example, sometimes incompatibility of interests can lead to conflicts between them. In this situation, companies should pay attention to the importance of the following five conditions:

1. Choosing a partner that suits the company, creation of communication channels, do not expect quick profits.

2. Compared with the company's nomenclature of goods it requires not a competitor, but choose an understudy partner. advantage.

3. To seriously study partnership technologies and production methods and get the maximum

4. Careful use of commercial information, if necessary, hide information even from partners.

5. View alliances as a temporary organization (5-10 years) continue cooperation if the situation requires.

Strategic goals and «profit reserves».

In international business practice in relation to a specific country the concept of "profit reserves" ${ }^{\prime \prime}$ is also applied.

"Profit reserve" is those country's market, in which a particular company will benefit from having a reliable, market position. For example, Japan is a "reserve" for its companies because the Japanese government set trade barriers against foreign companies so that in such conditions, foreign companies feel very awkward. There are many amenities for Japanese companies.

"Profit reserve" is a competitive factor based on trade protectionism and competitiveness of national companies. The paradox is that "profit reserves" are as far as active, the company's competitiveness will also be high.

In international business practice, the concept of "critical market" is used to combat global aggression. Critical market is a manifestation of those national market, in which:

- "profit reserves" are considered as an important factor of competitiveness;

\footnotetext{
${ }^{1}$ See Wilmer Guardado and Aaron Ranos.// https://www.quora.com/
} 
- most goods are made for sale;

- there are outstanding strategic clients of the company;

- low global aggression and low competitive pressure will contribute to high profits.

\section{REFERENCES}

1. Richard Pomfret. The Central Asian Economies in the Twenty-First Century: Paving a New Silk Road., Princeton University Press, 2019. // https://www.jstor.org/

2. Bernard Michael Gilroy. International Competitiveness, Multinational Enterprise Technology Clubs and the Government Interface. /Trade, Growth, and Economic Policy in Open Economies Essays in Honour of Hans-Jürgen Vosgerau. Springer Pages 13-30. // https://link.springer.com/

3. Sven W. Arndt. Globalization and the Gains from Trade /Trade, Growth, and Economic Policy in Open Economies Essays in Honour of Hans-Jürgen Vosgerau. Springer. Pages 3-12. // https://link.springer.com/

4. Arndt, S.W. (1996), International Sourcing and Factor Allocation in Preference Areas, prepared for the Workshop on International Trade and Factor Movements Between Distorted Economies, University of Konstanz, July 4-6. // http://hdl.handle.net/10419/101713

5. Paul Krugman. Competitiveness: A Dangerous Obsession., Foreign Affairs March/April 1994. //https://www.foreignaffairs.com/

6. Udo Broll. Intra-Firm Trade and Exchange Rate Risk. /Trade, Growth, and Economic Policy in Open Economies Essays in Honour of Hans-Jürgen Vosgerau. Springer. Pages 93-98. // https://link.springer.com/

7. Bernard Michael Gilroy. International Competitiveness, Multinational Enterprise Technology Clubs and the Government Interface. //Trade, Growth, and Economic Policy in Open Economies Essays in Honour of Hans-Jürgen Vosgerau. Springer Pages 13-30.

8. T. L. Brewer, 'An issue-area approach to the analysis of MNE-government relations', Journal of International Business Studies, 23(2) (1992)

9. Gilroy, B.M. (1989), Intra-Firm Trade, Journal of Economic Surveys 3, 325-343. Gilroy, B.M. (1993), Networking in Multinational Enterprises (The Importance of Strategic Allicances), University of South Carolina Press. //https://scholar.google.com/

10. Helpman, E. (1984), A Simple Theory of International Trade with Multinational Cooperations, Journal of Political Economy 92, Volume 92, Number 3 | Jun., 1984451-471. // https://www.journals.uchicago.edu/

11. Hipple, F.S. (1990), The Measurement of International Trade Related to Multinational Companies., The American Economic Review, Vol. 80, No. 5 (Dec., 1990), pp. 1263-1270//https://scholar.google.com/

12. Itagaki, T. (1981), The Theory of the Multinational Firm under Exchange Rate Uncertainty., The Canadian Journal of Economics / Revue canadienne d'Economique, Vol. 14, No. 2 (May, 1981), pp. 276297 //https://scholar.google.com/

13. Kawai, M. and I. Zilcha (1986), International Trade with Forward-Futures Markets Under Exchange Rate and Price Uncertainty, Journal of International Economics. Volume 20, Issues 1-2, February 1986, Pages 83-98 // https://www.sciencedirect.com/

14. Krugman, P.R. (1989), Exchange Rate Instability, MIT Press, Cambridge, London. Shapiro, A.C. (1991), Foundations of Multinational Financial Management, Boston: Allyn and Bacon.

15. Vosgerau, H.-J. (Ed.) (1989), New Institutional Arrangements for the World Economcy, Berlin: Springer-Verlag. 